\title{
Zinc Finger Protein 350
}

National Cancer Institute

\section{Source}

National Cancer Institute. Zinc Finger Protein 350. NCI Thesaurus. Code C98160.

Zinc finger protein 350 (532 aa, $\sim 60 \mathrm{kDa}$ ) is encoded by the human ZNF350 gene. This protein is involved in transcriptional repression. 